\title{
Prototype of the Turbo-Type Mini-Pump with an Impeller Driven Directly by Electro-Magnets and its Fundamental Pumping Characteristics
}

\author{
M. Yokoyama and T. Tsukiai* \\ Interdisciplinary Graduate School, Tokyo Institute of Technology, 4259, Nagatsuta-cho, Midori-ku, Yokohama 226-8502, Japan \\ *Yokogawa Electric Works Ltd., 2-9-32, Nakamachi, Musashino, Tokyo 180-8750, Japan
}

\begin{abstract}
Normal fluid-carrying pumps are classified into three types: turbo-type, volume-type, and others. This study deals with a newly developed turbo-type axial flow mini-pump, whose impeller is driven directly by electro-magnets with U-shaped cores located outside of the pipe. At the first step of this study, a prototype pump was produced, where a commercially available flat circular disc-type ferrite or neodymium permanent magnet is bonded adhesively to the top of each of the blades of the impeller, and this circular disc-type magnet is driven directly by eight electro-magnets. In the case of ferrite magnet, the magnet and the cores of electro-magnets are overlapped $10 \mathrm{~mm}$ in radial direction, but in the case of neodymium magnet, both are separated $2 \mathrm{~mm}$. At the second step of this study, the fundamental pumping characteristics of this turbo-type mini-pump, such as maximum rotation speed in air and in water, pump head and flow rate as a function of the rotation speed of the impeller, were measured and discussed.
\end{abstract}

Key words : pump, mini-pump, turbo-type pump, pumping system, directly driven pump, electro-magnet, impeller

\section{管路外からインペラが直接電磁駆動される ターボ型小形ポンプの試作とその基礎特性}

\author{
横山正明・突合利哉* \\ 東京工業大学大学院総合理工学研究科, 神奈川県横浜市緑区長津田町 4259（广226-8502） \\ *横河電機株式会社，東京都武蔵野市中町 2-9-32（干180-8750）
}

\section{1. はじめに}

通常の流体輸送用ポンプは大別すると，(1) ターボ型ポンプ， （2)容積型ポンプ，(3)その他ポンプ，に分けられる. いずれの ポンプにおいても，流体に直接触れてその流体に運動を与える インペラ (羽根車), ピストン, などのポンプ要素は回転軸, 往 復動軸, などの軸要素を介して外付けの電動機と結合され, 駆 動される形式が最も普通である．このとき，流体もれを防ぐた めにポンプ本体と軸要素の間にシーリングを施す.

ポンプ本体と軸要素の間のシーリングが不必要なポンプとし て，非接触磁石駆動方式によるポンプが「マグネットポンプ」 の名称ですでに多くの会社から市販されている. しかし，この タイプのポンプにおいては駆動用に外付けの電動機を使用して いるので，ポンプの小形化を図ることができない.

本研究は，MEUS 技術によってその要素が製作されるような， 非常に小さい, いわゆる「マイクロポンプ」と総称されるポン プを対象とするものではなく，駆動用に外付けの電動機を使用 しない方式の, 小形ポンプを対象とする. 前者のマイクロポン プに関しては, 文献1)あるいは2）において数多くの最近の研究 成果，開発事例がまとめて紹介されている.

外付けの電動機を使用しない小形ポンプの駆動源としては, 流体の気液相変化 $\left.{ }^{3)}, 4\right)$, 気泡 ${ }^{5)}$ を活用するもの, 形状記憶合金 ${ }^{6)}$,

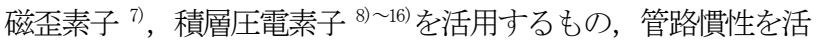

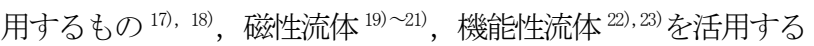
もの，電磁力を活用するポンプとして，インペラを電磁駆動す

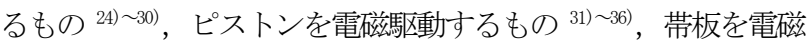

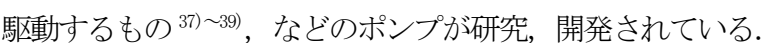

本研究は，外付けの電動機を使用せず，駆動源として電磁力
を活用する，新しいタイプのターボ型の軸流小形シールレスポン プを開発しようとするものである，すなわち，穴あき円板状永久磁 石が外周上に取り付けられたインペラを流体輸送用の管路 (パイプ) の外周上に配置された電磁石により非接触に直接電磁駆動する方 式のターボ型軸流小形シールレスポンプを開発しようとするもの である．外付けの電動機を使用しないので，ポンプの小形化を図 ることができる.

\section{2. 試作ポンプとその基礎特性}

本研究の初期の段階において，直交する 2 枚の平板状永久磁石 間に働く磁気力の作用原理を活用し，4枚の正方形平板状永久磁 石のブレードが回転軸に対して $45^{\circ}$ ねじれた状態に取り付けられ たインペラを，パイプ外周上に配置された 3 組 6 個の，ブレード に合わせてねじれた形のコアを有する電磁石によって非接触に直 接電磁駆動する方式のターボ型小形シールレスポンプを試作した. しかし，このポンプには，作用する磁気力に関して次のような問 題点があった：

（1）永久磁石面とコア面が直交しているために，永久磁石および 電磁石の固有の磁気力が有効に活用されていない,

（2） 3 組の電磁石のうち常時 1 組しか励磁されておらず，電磁石 が有効に活用されていない,

（3）コアが I 字形であるため，コアの外周から外側に向けて磁束 漏洩が発生するので，電磁石の磁気力がその分だけ弱くなる.

この問題点のために，この初期のポンプでは期待するほどの回 転トルクが得られず，したがって良好なポンピング特性は得られ なかった．そこで，そのポンピング特性を改善するために，これ らの問題点に配慮した，新しいタイプのターボ型小形シールレス 
ポンプ（以後，試作ポンプと呼称する）を考えた.

本章においてはこの新しいタイプのポンプ，すなわち分割着 磁された，穴あき円板状のフェライト磁石あるいはN NFeB 系磁石が 外周上に取り付けられたインペラを，パイプ外周上に配置された 電磁石によって非接触に直接電磁駆動するポンプを試作し, そ のポンピング特性を評価する.

\section{1 試作ポンプの駆動原理}

試作ポンプの構造の概略模式図をFig. 1 に示す. インペラ, 円 周方向 4 等分に分割着磁された平らな穴あき円板状永久磁石, お よびその永久磁石をはさみこむようなU字形コアを有する $8 つ$ の電磁石から構成される. 永久磁石はインペラと接着結合されて おり, 電磁石を繰り返し励磁することにより永久磁石を回転さ せ，この結果結合されたインペラも回転し，ポンピングを行う.

Fig. 1 においては, 図の煩雑さを少なくするために, 永久磁石 とコアは重ならないように図示しているが，実際には永久磁石 がフェライト磁石の場合には両者は重なって配置され, 永久磁 石がNdFeB系磁石の場合には両者は重ならずに離れて配置されて いる. Fig. 1 において図示されている電磁石の極性は, 円板状永 久磁石の磁極面に対面しているコア面, 寸なわちU字形コアの 内側面の極性を表している.

試作ポンプの回転原理を Fig. 2 に示す. 円板状永久磁石とそれ をはさみこむように周囲に等間隔に配置されている 8 つ電磁 石との極性関係が図(a)の状態にあるとき, 図(b)のようにブレ ードは時計回り方向に力を受ける. 電磁石を駆動側, 永久磁石 を従動側とすると, 永久磁石は $45^{\circ}$ 回転し, 図(c)の状態で止ま る. そののち, 図(d)のように電磁石 Bおよび電磁石Dの極性を 反転すると, 図(a)の状態が再現されることになり, 永久磁石は 再び同じ方向に回転運動を行う：このように8つの電磁石を向 かい合う 2 つの電磁石の極性が等しくなるように励磁し， 4 組 の電磁石を瞬時に逐次切りかえて励磁することにより, 永久磁 石，したがってインペラを励磁変化に同期して一方向に回転さ せることができる.

このときの制御電流は 4 相の矩形波電流である. インペラの 回転と電磁石の励磁の切りかえは同期しているので, 停止状態 からインペラを始動させるためには, 励磁切りかえ速度をイン ペラの回転に合わせて0から徐々に大きくする必要がある.こ の励磁切りかえ速度の増大はパソコン制御により実行している. 回転速度を大きくしすぎると，ブレード，したがってインペラ にかかる負荷の増大などの理由によって, インペラの回転は脱 調し，停止する.

\section{2 試作ポンプの概略構造}

2. 2.1 フェライト磁石を使用したポンプ 穴あき円板状永久磁 石として市販のフェライト磁石を使用した. このフェライト磁 石は, 外径 $48 \mathrm{~mm}$, 内径 $25 \mathrm{~mm}$, 厚さ $3.5 \mathrm{~mm}$, 表面の平均的な磁束 密度はおよそ $90 \mathrm{mT}$ である. このフェライトータイプの試作ポン プの概略模式図を Fig. 3 に示寸. U字形コアの内側面と永久磁 石面の半径方向の重なりは $10 \mathrm{~mm}$, 両者の表面の近接距離は 2. $25 \mathrm{~mm}$ に設計されている.

Fig. 4 にフェライトータイプの試作ポンプの全体写真を示寸. 見や寸くするために手前側の電磁石固定用溝付き円板が取り去

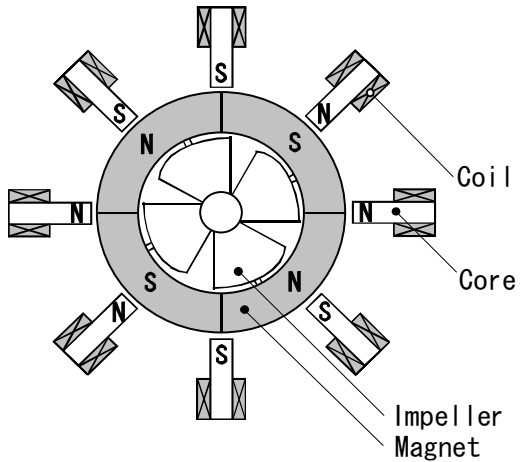

Fig. 1 Schematic structure of prototype pump.

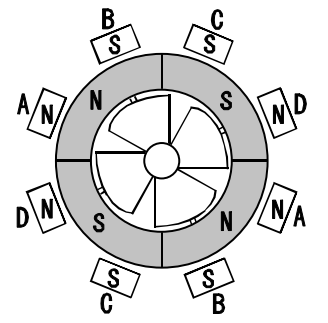

(a)

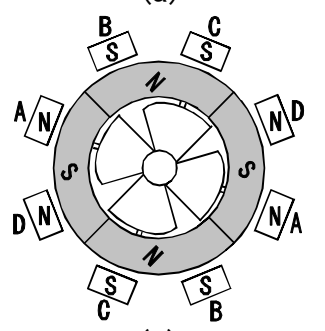

(c)

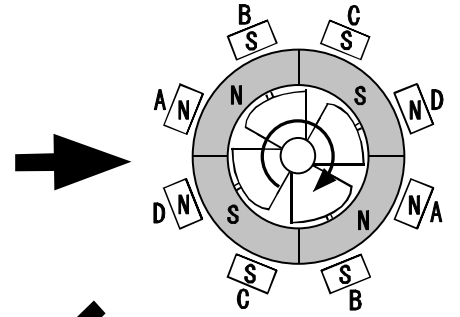

(b)

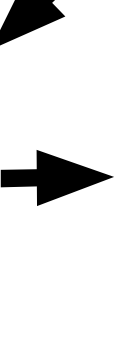

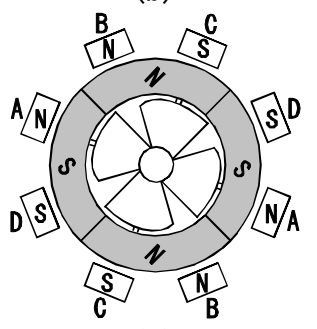

(d)
Fig. 2 Driving process of prototype pump.

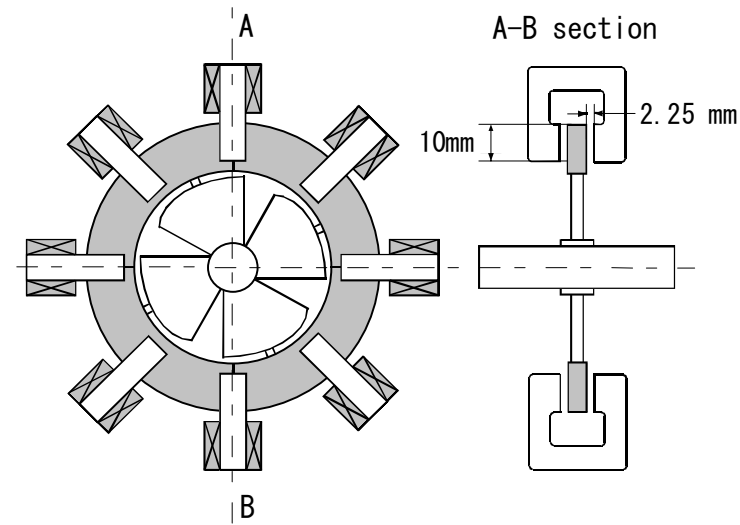

Fig. 3 Schematic structure of ferrite-type pump.

られている. 外径 $28 \mathrm{~mm}$, 内径 $24 \mathrm{~mm}$ のパイプ径減少部分の外周上に コアとコイルから構成される $80 の$ 電磁石が等間隔に取り付けら れている. パイプ内には Fig. 5 に示される永久磁石とインペラが が両側すべり軸受され，収納されている．コアは厚さ $1 \mathrm{~mm}$ のパー マロイを 10 枚貼り合わせて製作されており，コアのまわりに直径 $0.5 \mathrm{~mm}$ の銅線を 50 巻して電磁石を形成している.

Fig. 5 に接着接合された永久磁石とインペラの写真を示す. 平板 状のブレードは回転軸に対して $45^{\circ}$ ねじれた状態で取り付けられ 


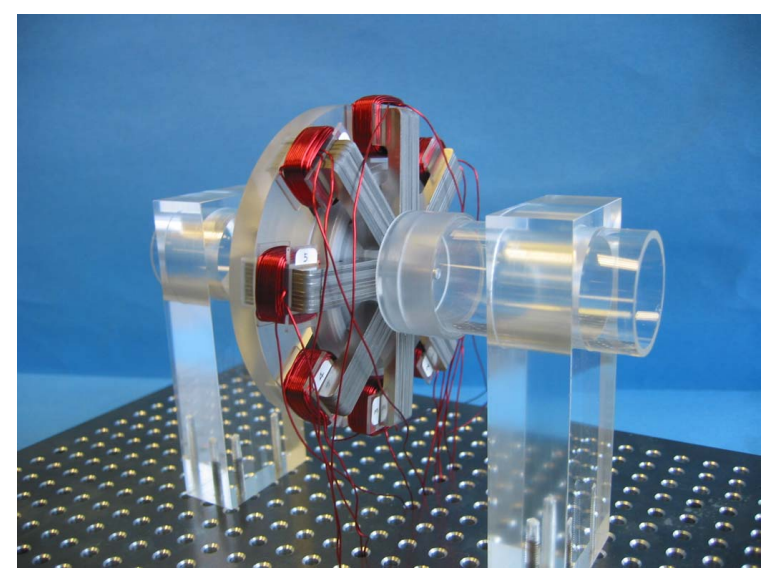

Fig. 4 Photograph of ferrite-type pump.

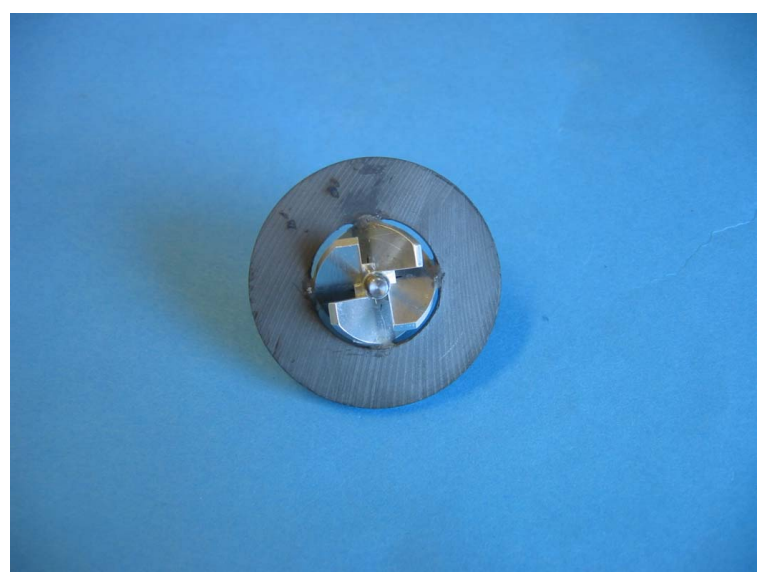

Fig. 5 Photograph of an adhesively bonded permanent magnet and impeller.

ており，半径方向にはパイプ内壁とのすきまが一様になるよう にだ円形状に作成されているのが分かる.

2. $2.2 \mathrm{NdFeB}$ 系磁石を使用したポンプ 永久磁石か強力であれば ポンプも強力になるだろうとの予測から, 穴あき円板状永久磁石と して市販の $\mathrm{NdFeB}$ 系磁石を使用した NdFeB 系ータイプのポンプも 同時に試作した. $\mathrm{NdFeB}$ 系磁石の幾何学的寸法はフェライト磁石 と同一であり, 表面の平均的な磁束密度はおよそ 400mT である.

この $\mathrm{NdFeB}$ 系ータイプポンプの場合, フェライトータイプポン プのようなコアと永久磁石の半径方向の重なりはゆるされず, コアの先端と永久磁石の外周は $2 \mathrm{~mm}$ 離れて配置されている.

\section{3 試作ポンプのポンピング特性}

電磁石のコイルに最大值 $3.1 \mathrm{~A}$ の 4 相の矩形波状の制御電流を 流して，試作ポンプのポンピング特性を測定した.

2.3.1 回転特性 フェライトータイプと $\mathrm{NdFeB}$ 系ータイプの 2 タ イプのポンプについて, 空気中および水中において脱調せずに インペラが回転する最大回転速度を求めた結果を Table 1 に示 す. この Table 1 を見るに, U字形コアの内側面と永久磁石面 に半径方向に $10 \mathrm{~mm}$ の重なりがあるフェライトータイプポンプと 両者が半径方向に $2 \mathrm{~mm}$ 離れている $\mathrm{NdFeB}$ 系ータイプポンプの回転 特性に大きな差異がないことが分かる.

2.3.2 揚程特性 試作ポンプの吸入側, 吐出側に外形 $30 \mathrm{~mm}$, 内
Table 1 Maximum rotation speed of the impeller in air and in water.

\begin{tabular}{|l|c|c|}
\hline & Ferrite-type & NdFeB-type \\
\hline $\begin{array}{l}\text { Maximum rotation } \\
\text { speed in air [min }\end{array}$ & 3662 & 3662 \\
\hline $\begin{array}{l}\text { Maximum rotation } \\
\text { speed in water [min }\end{array}$-1] & 3052 & 2930 \\
\hline
\end{tabular}

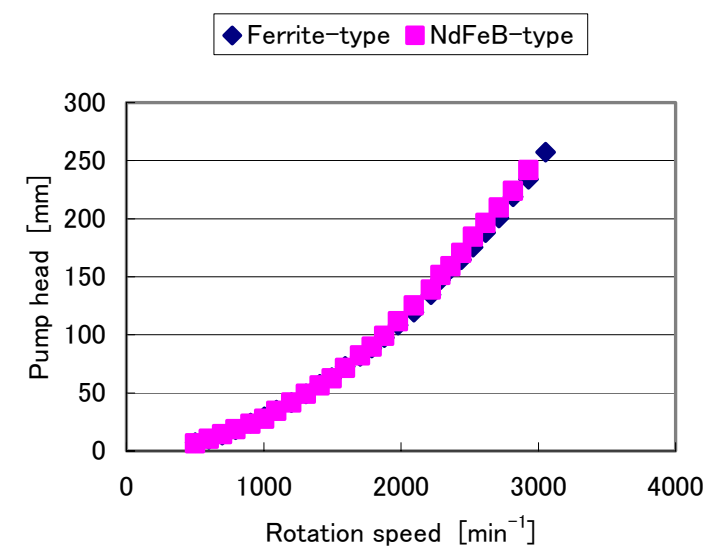

Fig. 6 Pump head as a function of the rotation speed of the impeller.

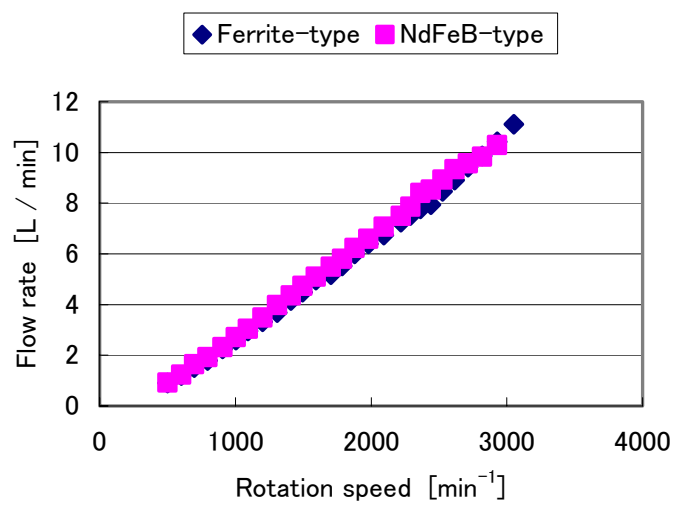

Fig. 7 Flow rate as a function of the rotation speed of the impeller.

径 $26 \mathrm{~mm}$ のパイプを鉛直に立て，その中に水を満たして両者の水面 を同じ高さにする．そののちポンプを始動し，水面の動きが定常 状態になったときに両者の水面の高さの差を読み取る方式によっ て揚程を測定した.

インペラの回転速度を変化させ，フェライトータイプと $\mathrm{NdFeB}$ 系 ータイプの 2 タイプのポンプについて測定した結果をFig. 6 に示寸 最大揚程はフェライトータイプポンプの場合の $257 \mathrm{~mm}$ であるが，両 タイプのポンプの揚程特性に大きな差異はない.

2.3.3 流量特性 ポンプの吸入側には大き目のタンクを設け，吐 出側に外形 $30 \mathrm{~mm}$ ，内径 $26 \mathrm{~mm}$ のパイプをつないで，両者の水面を同 
じ高さにする方式の装置を用い，インペラを回転させたとき単 位時間あたりパイプ内を流れる水の流量を測定した. インペラ の回転速度を変化させ，フェライトータイプと $\mathrm{NdFeB}$ 系ータイプ の 2 タイプのポンプについて測定した結果を Fig. 7 に示す. 最 大流量はフェライトータイプポンプの場合の $11.12 \mathrm{~L} / \mathrm{min}$ である が，両タイプのポンプの流量特性に大きな差異はない.

\section{4 考察}

本研究の初期に試作した，4枚の正方形平板状永久磁石のブ レードを有するインペラを, パイプ外周上に配置された電磁石 によって非接触に直接電磁駆動する方式の小形ポンプの有した 問題点に配慮して, 本研究では穴あき円板状の永久磁石が外周上に 取り付けられたインペラを, U字形コアを有する電磁石によりパ イプ外から非接触に直接電磁駆動する, 新しいタイプの小型ポ ンプを試作し, 円板状磁石がフェライト磁石の場合には, ポンプ は期待どおりに動作することを確認した.

しかし, 円板状磁石がNdFeB 系磁石の場合には, 円板状磁石とU字 形コアの間に半径方向の重なりがあるとき, プラスチックケーシング およびすべり軸受の軸方向岡性が小さいため, コアと円板状磁石の強 い相互引力によって円板状磁石が軸方向に移動し, 隔壁に接触してイ ンペラは回転できなかった. ケーシングを非磁生の金属構造にし， 軸受をころがり軸受にして軸方向岡性を大きくすれば, 円板状磁石が $\mathrm{NdFeB}$ 系磁石の場合でも，その軸方向移動，したがって隔壁との接触 はなくなり，インペラは回転できるようになると考える.

本研究以降の試作ポンプにおいては, ポンプケーシングの構造 岡性の増大, 内輪の軸力向移動が拘束されている形式のころがり軸受 の採用, および流線形ブレードの採用, 等々構造面への配慮, 改 善を実施したいと考えている.

\section{3. まとめ}

外付けの電動機を使用せず，パイプ外周上に配置された電磁 石によってインペラを非接触に直接電磁駆動する, 新しいタイ プのターボ型の軸流小形シールレスポンプに関する基礎的な実 験研究を行った. 得られた成果は，以下のようにまとめられる： (1) 4 分割着磁された, 平らな穴あき円板状のフェライト磁石あるい はNdFeB 系磁石が外周上に取り付けられたインペラを, パイプ外周 上に配置された，U字形コアを有する電磁石によって直接電磁 駆動する方式の，新しいタイプの軸流小形ポンプを試作し，円 板状磁石がフェライト磁石の場合には，この円板状磁石と電磁石コ アに半径方向に $10 \mathrm{~mm}$ の重なりがあるときにも, 期待どおりにポン ピング動作することを確認した.

（2）しかし，穴あき円板状磁石が NdFeB 系磁石の場合，この円板状 磁石と電磁石コアに半径方向の重なりがあるときには, プラスチッ クケーシングおよびすべり軸受の軸方向岡性が小さいため, 円板状 磁石とコアの強 相互引力によって円板状磁石が軸方向に移動し, 隔壁に接触してインペラが回転できないことが分かった. (3)この場合, 円板状磁石の外周と電磁石コアの先端の間に半径方 向に $2 \mathrm{~mm}$ 程度の寸きまを与えるとインペラは回転でき, 円板状磁 石がフェライト磁石の場合のポンプとほほ同程度の回転特性，ポン ピング特性が得られることが分かった。

\section{References}

1) T. Higuchi (ed.) : Micromachine Gijutsu Sohran (in Japanese), 663(2003).

2) P. Woias : Sensors and Actuators (B), 10, 28(2005).

3) K. Ozaki : Proc. 8th IEEE Work-Shop on Micro Electro Mechanical Systems (MEMS’ 95), 31(1995).

4) H. Takagi, et al. : Proc. 5th Int. Symp. on Micro Machine and Human Science, 199(1994).

5) K. Miyazaki, et al. : Turbo-machinery (in Japanese), 29, 48(2001). 6) E. Makino, et al. : Sensors and Actuators(A), 88, 256(2002).

7) K. Kaneda, et al. : Kokai Tokkyo Koho JP1994-197573(1994). 8) H.T.G. VanLintel : Sensors and Actuators, 15, 153(1988). 9) J.H. Park, et al. : J. Robotics and Mechatronics, 9, 687(1999). 10) J.H. Park, et al. : JSME Int. J., 45C, 502(2002).

11) J.H. Park, et al. : Proc. Actuator 2002, 240(2002).

12) M. Kimoto, et al. : Turbo-machinery (in Japanese), 31, 435(2003).

13) J.H. Park, et al. : Proc. Actuator 2004, 557(2004).

14) J.H. Park, et al. : J. Robotics and Mechatronics, 16, 171(2004).

15) Hagitec Co. : http://www.hagitec.co.jp/.

16) Star Micronics Co. : http://www.star-micronics.co.jp/.

17) T. Seto, et.al. : J. Robotics and Mechatronics, 15, 128(2003).

18) K. Yoshida, et al. : Proc. Int. Conf. on Fluid Power, 394(2005).

19) A. Hatch : J. MEMS, 10, 215(2001).

20) Y. Takasaki : Kokai Tokkyo Koho JP2003-074462(2003).

21) K. Ozaki, et al. : http://www.aist.go.jp/.

22) W.S. Seo, et al. : Proc. First Joint Int. Conf. on Manufacturing,

Machine Design and Tribology, CD-Rom MAA-204, (2005). 23) S. Yokota, et al. : Proc. Int. Conf.. on Fluid Power, 234(2005). 24) T. Akamatsu, et al. : Artificial Organs, 16, 305(1992).

25) I. Nishimura, et al. : J. American Society for Artificial Internal Organs, 49, 744(2003).

26) T. Yano, et al. : Artificial Organs, 27, 920(2003).

27) J. Asama, et al. : J. American Society for Artificial Internal Organs, 50, 550(2004).

28) H. Hoshi, et al. : J.American Society for Artificial Internal Organs, 51,60 (2005).

29) S. Nagano : Kokai Tokkyo Koho JP1998-077996(1998). 30) MicroMed Technology, Inc. : http://www.micromedtech.com/ 31) M. Noguchi, et al. : Kokai Tokkyo Koho JP1994-159232(1994). 32) M. Iwami : Kokai Tokkyo Koho JP1995-004875(1995). 33) Y. Murata : Kokai Tokkyo Koho JP1998-077961(1998). 34) S. Masuda : Kokai Tokkyo Koho JP2000-045934(2000). 35) Y. Ogawa : Kokai Tokkyo Koho JP2001-027175(2001). 36) A. Kaneko : Kokai Tokkyo Koho JP2003-328929(2003). 37) T. Honda, et al. : IEEE Trans. on Magnetics, 34, 2102(1998). 38) K. Kondo, et al. : J. Magn. Soc. Jpn., 26, 612(2002). 39) K. Kondo, et al. : J. Magn. Soc. Jpn., 27, 499(2003).

2005 年 9 月 8 日受理, 2005 年 11 月 15 日採録 